\title{
Production of refined red palm-pressed fibre oil from physical refining pilot plant
}

\author{
Nur Sulihati Abd. Wafti ${ }^{1}$, Harrison Lau Lik Nang ${ }^{1}$, Nur Azreena Idris ${ }^{1}$, and Nabilah \\ Kamaliah Mustaffa ${ }^{1}$ \\ ${ }^{1}$ Malaysian Palm Oil Board
}

April 28, 2020

\begin{abstract}
Palm-pressed fiber oil (PPFO) is unique as it contains higher amount of carotenoids, vitamin E (tocotrienols \& tocopherols) and other phytonutrients (squalene and sterols) as compared to crude palm oil (CPO). However, crude PPFO has high phosphorus content and free fatty acid (FFA) and at the same time low in deterioration of bleachability index (DOBI) that requires specific refining steps for achieving a good quality oil properties. The physical refining pilot plant scale was developed, involved a combination of step including wet and acid degumming and bleaching followed by high vacuum deacidification. The optimum refining conditions comprises wet degumming using $5.0 \mathrm{wt} / \mathrm{wt} \%$ of distilled water at $90^{\circ} \mathrm{C}$ for $20 \mathrm{~min}$, acid degumming using $0.5 \mathrm{wt} \%$ of phosphoric acid at $90^{\circ} \mathrm{C}$ for $10 \mathrm{~min}$, bleaching using $1.0 \mathrm{wt} \%$ of natural bleaching earth at $105^{\circ} \mathrm{C}$ for $20 \mathrm{~min}$, and deacidification at $160^{\circ} \mathrm{C}$ and $0.001 \mathrm{mmHg}$. A significant reduction of phosphorus content of $97 \%$ (from $633 \pm 83 \mathrm{ppm}$ to $11 \pm 2$ ppm) and FFA of $91 \%$ (from $5.30 \pm 0.19 \%$ to $0.35 \pm 0.09 \%$ ) were achieved in the pilot scale study. The DOBI value of refined red PPFO improved from $2.02 \pm 0.18$ to $2.68 \pm 0.04$. Besides, the carotenoids $(986 \pm 55 \mathrm{ppm})$ and vitamin E (1075 $\pm 64 \mathrm{ppm})$ in refined red PPFO were preserved by applying the mild temperature of deacidification. The pilot scale results establish a significant contribution to the feasibility of the refined red palm-pressed oil.
\end{abstract}

\section{Hosted file}

Manuscript - Nur Sulihati Marsyila.doc available at https://authorea.com/users/309838/articles/ 440702-production-of-refined-red-palm-pressed-fibre-oil-from-physical-refining-pilot-plant 